\title{
Testimony Under Threat: Women's Voices and the Pursuit of Justice in Post-War Sri Lanka
}

\author{
Kristine Höglund ${ }^{1}$ (D) \\ Published online: 11 March 2019 \\ (C) The Author(s) 2019
}

\begin{abstract}
This paper foregrounds how women's public testimony as part of a formal transitional justice initiative is shaped by the particular context in which a commission operate, including the political and security environment. While the literature has engaged with the gendered predicaments of truth commissions after peace agreements and during transitions away from non-democratic rule, the function of such initiatives in more authoritarian and in immediate post-war contexts is generally overlooked. I examine women's testimonies from Sri Lanka's Lessons Learned and Reconciliation Commission (LLRC), and contend that pervasive militarization and insecurity, and the conduct of the Commission, influenced the stories that came forth. Women's testimonies in the war-torn areas primarily represent pleas for information about missing family members and reflect important silences about the women's own experiences of abuse, including ongoing post-war insecurities. The analysis raises questions about what may be expected from transitional justice efforts in difficult post-war contexts.
\end{abstract}

Keywords Gender · Sri Lanka · Public testimony $\cdot$ LLRC $\cdot$ Human rights · Transitional justice

\section{Introduction}

Women testifying about their wartime experiences, in settings ranging from international court rooms to grassroots-initiated storytelling and oral history projects, have been vital for challenging conventional understandings of women's experiences during war, their post-war concerns, and expected roles in society (Buckley-Zistel and Stanley 2012; Butalia 2000; Kent 2016; Porter 2016). Women's testimonies have cracked open deeply cemented silences around women's suffering and offered a more

Kristine Höglund

Kristine.Hoglund@pcr.uu.se

1 Department of Peace and Conflict Research, Uppsala University, Box 514, 75120 Uppsala, Sweden 
multidimensional depiction of the insecurities facing women (Björkdahl and Mannergren Selimovic 2014; Karstedt 2010; McLeod 2013; Mibenge 2013; Porter 2016; Theidon 2007).

Public testimony as part of transitional justice efforts, thus, holds both the potential to transform the social and political order, as well as the capacity to cement existing power relations. Previous literature conceptualizes institutionalized and public inquiries into war-related atrocities as important sites reflecting existing gender dynamics, but also as producers of gendered public narratives (Ross 2003; Rosser 2007). By now there is a large body of research excavating the gendered nature of transitional justice mechanisms, and important scholarly work highlighting the significance of survivors' stories in both formal and informal testimonies (e.g., Kent 2014; Meyers 2016; Rosser 2007; Stover 2007). However, while the literature has engaged with the gendered predicaments of truth commissions in the wake of peace agreements and transitions from non-democratic rule to democracy, women's roles in such initiatives in more authoritarian and immediate post-war contexts remains largely overlooked (c.f. Grodsky 2008; Pereira 2003). In this article, I uncover how the types of stories that are represented in public testimony are contingent on the timing of the initiative, and the political environment in which the public hearings are held.

To this end, I examine themes from transcripts of witness statements by women who testified in Sri Lanka's Lessons Learned and Reconciliation Commission (LLRC). Portrayed by the government as an effort to promote reconciliation and learning for the future, the LLRC initiative came about in a situation marked by a glaring power asymmetry and a high level of militarization, where the government came to dominate the discourse and practice on transitional justice. Starting its work in 2010, only a year after the war ended, the statements from the hearings of the LLRC constitute a public record of war-related representations in the immediate post-war period. The LLRC received more than 5000 written submissions and 1000 oral submissions from a diverse range of individuals and organizations. Focus is on witness statements from public hearings conducted in the most conflict-affected areas of Sri Lanka: districts in the Northern Province (Jaffna, Kilinochchi, Mannar, Mullaitivu, and Vavuniya) and in the Eastern Province (Ampara, Batticaloa, and Trincomalee).

Sri Lanka constitutes an important case for exploring how the timing and context shape the public testimonies by women in a formal and public fact-finding commission with the official aim of reconciliation. Between 1983 and 2009, Sri Lanka experienced an ethnically based armed conflict with the government and the separatist Liberation Tigers of Tamil Eelam (LTTE) as its main protagonists. The final years of the war saw an unprecedented intensification of the violence, with major atrocities committed by both sides. The immediate post-war period held distinct challenges for reconciliation and justice due to the overwhelming victory by the government, which had ended the military conflict. In particular, the LLRC operated in an environment marked by a stark power asymmetry, government control, high levels of militarization, and widespread fear.

This study, thus, adds to the literature on gendered dimensions of transitional justice processes by uncovering the predicaments of formal testimony given by women in a very difficult context. The LLRC remains a hitherto underexplored source of public testimony. With a few exceptions (e.g., Fonseka 2017; Gunatilleke 2015; Thiranagama 2013), most studies of transitional justice in Sri Lanka mention the LLRC only in brief and do not place representations by women witness statements in focus. de Mel's 
gendered analysis of the LLRC (de Mel 2013) engages specifically with women's testimonies from the LLRC and draws on a focus group interview with five women in Batticaloa (Eastern Province). It asks questions about how justice is defined by the women testifying and what the women hoped to achieve with their testimonies. Here I revisit the LLRC with an analysis of all available testimonies by women in the war-torn north and east of Sri Lanka to foreground the importance of context and timing for what is represented in the testimonies.

With the benefit of hindsight, I read the testimonies in light of growing insight about the gendered nature of the war and the post-war context in which the LLRC was operating. In doing so, I uncover more general issues related to voice and silence represented in public testimonies by women survivors after war. Specifically, I show how the testimonies are contingent on the timing and conditions of the hearings, and also how the types of stories emerging reflect the underlying gender relations in society.

\section{Post-War Testimonies and Women}

Scholarship on transitional justice processes has increasingly paid attention to the condition under which public testimony are given and the gendered nature of such processes. Research in diverse settings has documented how the experience of women survivors giving witness often is one of silencing, disrespect, and humiliation, and that many women experience psychological illhealth, new insecurities, and retraumatization in the wake of testifying (e.g., Brounéus 2008; Franke 2006, p. 813; Hamber and Wilson 2002). Yet, women testifying about their wartime experiences-in both formal and informal settings - have also served to empower and give voice to experiences and roles by women previously unacknowledged (e.g., Björkdahl and Mannergren Selimovic 2014; Butalia 2000; Porter 2016; Theidon 2007).

In this article, I am concerned with how the timing and context are important for understanding the gendered nature of public testimony as part of transitional justice efforts. Women who bear witness do so with a particular audience in mind. The particular site, context, and timing will shape expectations of the individuals giving testimony, how stories are told, and which themes are privileged. In many settings, especially formal ones, expectations of those giving witness are scripted and limited for several reasons (Kent 2014; Nesiah 2006; Ross 2003; Schaffer and Smith 2004; Stover 2007). Thus, we can expect silences around certain themes, while other experiences are more likely to be represented.

A first issue relates to how procedural constraints and the logic of formal truth-telling script the agency of the witness. In terms of procedures, the mismatch between the legal imperative to confirm factual evidence, especially in court rooms, and the witnesses attempts to tell their stories and relate their experience/feelings is well-established. Court testimonies do not allow for talking about historical context (Henry 2009; Stover 2007). Similarly, in truthtelling initiatives, the focus on establishing factual truth can overshadow the cathartic component of giving testimony. Moreover, Western/international norms underpinning international courts and many domestic truth-telling initiatives may run counter to local practices of justice and incentivize the telling of some 
stories over others (Baines and Stewart 2011, p. 247; Hinton 2010). For instance, representations in such forums are commonly concerned with events, dates, and facts, while testimony in informal settings may have other functions, such as restoring the narrator's place in society (Kent 2016).

Second, the motives for and expected outcomes of coming forward to testify will also matter for which experiences are represented. For instance, many witnesses are motivated by a sense of moral duty and testify in place of those who can no longer voice their suffering, while others hope that giving testimony will help defeat feelings of humiliation (Stover 2007). Witnesses in public truth-telling initiatives also develop expectations of reciprocity or compensation, for example in the form of reparations, which influence the stories told. However, when expectations are not fulfilled, truth-telling may reify existing power imbalances and reinforce perceptions of being marginalized (Guthrey 2016; Theidon 2007).

Thirdly, testimonies may also be dictated by existing local and international discourses and gender constructions. Indeed, narratives around peace and war are dominated by expectations and representation of women as victims without due consideration of the multitude of roles women have played during war, as survivors, perpetrators, leaders, and breadwinners (Kent 2014; Mibenge 2013; Rosser 2007; Sen 2011). Ross' analysis of the South African Truth and Reconciliation Commission (TRC) distinguishes between two forms of testimonies by women that are common: (1) expert witnesses in relation to the men in their lives (sons, husbands, etc.), so-called secondary witnesses, and (2) witnesses of sexually motivated crimes (Ross 2003, pp. 17-26). In essence, women testifying during transitional justice processes are likely to be influenced by the roles ascribed to women by the gender constructions present in a particular social context.

Interlinked with the above issues is the focus of this paper: the context in which public testimony is given and the timing of a particular transitional justice initiative. The particularities of the post-war setting will foreclose certain testimonies, and privilege others. At the political level, official truth commissions with the explicit aim of contributing to reconciliation may, as highlighted by Wilson (2001), be a means by which political elites evade accountability while still pursuing the ideas of co-existence. The launch of a public inquiry can also be a political strategy by a government, including to counter external pressure (Rowen and Rowen 2017). Post-war realities may include persistent militarization and manifest asymmetric power relationships between victims and perpetrators that influence witnesses also in more subtle ways (Alcalá and Uribe 2016). At the individual level, individual fears of reprisal interplay with the political situation. However, even in more permissive political environments, traumatic experiences may be particularly difficult to disclose (Theidon 2007; Henry 2009).

Public testimonies also contain a temporal dimension which influences their content. Scholars note how the transitional justice discourse conceptualizes distinct phases of war and peace, failing to account for the continuities between war and post-war (Moon 2006; Mueller-Hirth and Rios Oyola 2018). Yet many post-war settings are marked by insecurities and chronic violence entrenched in structural inequalities. For certain groups, the post-war era poses new security challenges and can make it difficult to raise sensitive and politically controversial issues (McLeod 2013). 


\section{The Sri Lankan Conflict, Women, and the Post-War Context}

The LLRC was formed after a decisive end to a longstanding armed conflict between the Tamil rebels LTTE and the Sinhalese-dominated government, the beginning of which is dated to 1983. By the outbreak of the war, the conflict had been simmering for years with recurring spates of violence between the Sinhalese majority and the Tamil minority. The conflict had its origin in the state-building process that followed independence in 1948, where reforms that favored the Sinhalese over other ethnic groups in the country were initiated. ${ }^{1}$ Policies were introduced that restricted minority rights, as well as educational and employment opportunities for the Tamils. Most notable was the legislation in 1956 that replaced English with Sinhala as the official language. What began as protest against the "Sinhalesation of the state" and demands for equal rights, eventually developed into a LTTE-led armed struggle for Tamil self-rule. While the defeat of the LTTE ended organized violent struggle, many of the underlying issues that led to the conflict in the first place remain to date, including the "uneven power relations that characterised wartime Sri Lanka-between ethnic and religious groups, between rich and poor, and between men and women" (Orjuela 2010, p. 10).

From a gender perspective, Sri Lanka poses a puzzle. Relative to other South Asian countries, women scores high on development indicators and the universal right to vote was enshrined in the constitution already in 1931. Yet, in terms of gender balance, there are a number of concerns including a very low representation of women in the national parliament as well as in the provincial councils and local government, ${ }^{2}$ and there are inconsistencies in the constitution concerning land and marriage (Wickramasinghe and Kodikara 2012; Pinto-Jayawardena and de Almeida Guneratne 2010). The vulnerable position of women in the plantation sector, employed in the free trade zone in Sri Lanka, and as migrant workers in the Middle East is also well-documented (de Mel 2012; Gamburd 2011). Moreover, violence against women is widespread (Perera et al. 2011).

The war has left several legacies with implications for gender relations. Women have participated in the armed struggle, suffered displacement, and sexual and gender-based violence, and have also been a force in peace-promotion efforts (de Alwis 2002; Hoole et al. 1990; Kottegoda 2010). ${ }^{3}$ Already in the early 1980s, women groups spearheaded human rights action and protest and have been a progressive force in many subsequent peace initiatives (Samuel 2001, 2017). The final stages of the war had a major impact on people residing in the north and east, the main battle sites. In Eastern Province, a large number of people were displaced in 2006 and 2007, when the Sri Lankan forces took control over the territory. The Northern Province also witnessed mass displacement and a large number of civilians were affected by fighting. Women held in internment camps in 2009 and 2010 were subject to sexual violence. "An

\footnotetext{
${ }^{1}$ The Sinhalese constitutes about $75 \%$ of the population, while the Tamil minority about $18 \%$ of the population.

${ }^{2}$ To exemplify, representation in parliament has been around 5\% and in local government less than $2 \%$ (Wickramasinghe and Kodikara 2012). A constitutional amendment passed in 2016 requires that $25 \%$ of the parties' political candidates in local elections are women, and when first applied in the 2018 local council elections, a record number of women contested the election. However, several analyses document the informal hurdles facing women's participation in politics, including intimidation of women candidates (e.g., de Sayrah and Wickrematunge 2018; Rameez 2018).

${ }^{3}$ Rajasingham-Senanayake (2004) describes how Tamil women during the war expressed agency and empowerment by assuming new roles as heads of households, breadwinners, and armed combatants.
} 
estimated 3,000 captured or surrendered women LTTE fighters-many of them forcibly recruited-were sent to military-run rehabilitation centers, where, again, there are credible allegations of rape and sexual abuse" (International Crisis Group 2017 , p. 7). Research also records substantial sexual violence during the war against both men and women in Sri Lanka (Traunmüller et al. 2017; Sooka 2014).

Militarization has remained a pervasive feature of post-war Sri Lanka, with many women relying on the military for their everyday needs (de Mel 2007; Gowrinathan and Cronin-Furman 2015; Satkunanathan 2018). The conflict, combined with social change, has resulted in a rise in women-headed households in the war-torn areas (Ruwanpura 2006; Samuel 2001), a condition that has persisted after the war and make women vulnerable to physical, economic, and other societal insecurities (Sarvananthan et al. 2017; Thaheer et al. 2013; Sivachandran 2013). A household survey from 2012 to 2013 estimates that a quarter of the households in the north $(58,000)$ are headed by women (Department of Census and Statistics 2015, p. 74).

The means by which the war concluded in 2009 , with an overwhelming military victory by the Sri Lankan army and the annihilation of the LTTE, shaped the post-war period, including reconciliation and justice efforts. In this period, Sri Lanka also saw a move towards authoritarianism, with President Rajapaksa consolidating power and diluting the democratic system through constitutional changes (DeVotta 2010; Jazeel and Ruwanpura 2009). Processes of demobilization and reintegration were not focused on truth-seeking and accountability. Instead, a large number of persons, by the government labeled as LTTE cadres, were arbitrarily detained under Emergency Regulations for extended periods of time. Concerns were raised about disappearances and illtreatment in custody, in some cases even following release (International Crisis Group 2011b). For those living in the war-affected areas during the Rajapaksa regime, there was limited space to organize public events to mourn the dead. In fact, attempts by Tamil communities in the north to commemorate the lives lost were hindered by the military (Ruwanpathirana 2016, pp. 21-22). The government objected to international pressure for accountability of war crimes, most importantly the UN Panel of Experts Report of 2010 and a sequence of resolutions at the UN Human Rights Council in Geneva. ${ }^{4}$ In this context, the LLRC, set up in May 2010, was launched as a government-driven and "home grown" initiative and remained operative until it delivered its final report in December 2011 (see more below).

Looking at post-LLRC developments, regime change in January 2015 opened up space within civil society to renew focus on transitional justice and reconciliation. In contrast to the Rajapaksa regime, the Sirisena government co-sponsored a UNHRC resolution in 2015, where a TRC and offices of missing people were to be created. The resolution also called for the investigation into war crimes, and a special court involving foreign judges and experts (UNHCR 2015). Moreover, a Secretariat for Coordinating Reconciliation Mechanisms was established and a Consultation Task Force (CTF) appointed in January 2016. The CTF held public consultations across Sri Lanka on the government's transitional justice policies, and its final report (published in January 2017) held far-reaching recommendations on how to proceed with the promotion of justice and reconciliation. In parallel, the process of establishing an Office

\footnotetext{
${ }^{4}$ Sri Lanka has a long history of impunity with only a few cases where war-related perpetrators have been tried and victims have received compensation or official recognition (Anonymous 2011).
} 
of Missing Persons was initiated, but in spite of parliamentary approval for its establishment in August 2016, it has not become fully operational.

\section{The LLRC and the Witness Statements}

The LLRC was to a large extent a response to pressure on the Sri Lankan government from the international community to take action on issues related to accountability. It was launched in May 2010 as a home-grown process aimed at contributing to reconciliation. Eight commissioners were appointed by the President, tasked with a mandate that involved fact-finding for the period between February 21, 2002 and May 19, 2009, to promote lessons for the future including recommendations concerning compensation, and to establish if "any person, group, or institution directly or indirectly bear responsibility in this regard" (LLRC 2011, p. 5). The mandate was unspecific on a number of accounts. For instance, the time period was very limited, the forms of violence to be investigated were not specified, and human rights violations were not mentioned. The choice of commissioners was subject to criticism because they were seen as being too close to the government (all of them had worked for the government at some point). In essence, the LLRC was criticized for being government-biased, its limited mandate, and being unable to deal with the accountability issue (Amnesty International 2011; Centre for Human Rights 2011; Thiranagama 2013).

Despite the criticism, the Commission received a significant number of written and oral testimonies. The Commission held 52 public hearings and the final report, released in December 2011, exceeded the expectations of critical observers. It made recommendations for wide-reaching institutional reforms and efforts aimed at reconciliation. It also included a section with recommendations on how to address the concerns of women in the war-torn areas. However, the influence of the LLRC on the relationship between the communities in Sri Lanka must be considered very limited. While some civil society organizations attempted to mobilize support and discussions based on the report, the Rajapaksa government lacked the political will to implement most of its recommendations.

In this article, the witness statements from the LLRC are approached as an important historical record showcasing how men and women choose to represent their war-related experiences and concerns at that given point in time. The core material analyzed are witness statements by women from the war-torn Northern and Eastern provinces of the country. The Commission received more than 5000 written submissions and 1000 oral submissions from a diverse range of individuals and organizations. The Commission visited 12 districts outside the capital Colombo, including all the war-torn districts in the Northern and Eastern provinces, in addition to a few districts in the southern parts of the country. In focus here are the witness statements given orally to the Commission during field visits to the war-affected areas.

By zooming in on how the individual testimonies represent experiences during the war, as well as concerns about the immediate and long-term future, issues related to the context of witnessing and their implications for voice and silence are probed: What experiences by women are portrayed? How are experiences and suffering given voice? What remains absent or silenced? How are gender power relations reflected and how is power expressed? In the analysis, the core themes identified are discussed in relation to 
the timing and context of the commission to make sense of why some experiences are represented, while other experiences remain hidden.

Some methodological challenges have arisen in the process of collecting and analyzing the witness statements that warrant discussion. First, not all statements have been made publically available and the quality of the transcripts is uneven in terms of length and detail. The LLRC had an official website (no longer active), where written submissions and transcripts from the field hearings, translated into English, were made publicly available and downloadable. ${ }^{5}$ It has not been possible to establish with certainty why some statements are missing, making it difficult to assess how the material might be biased. While there were in-camera sessions, which were completely off the record and therefore not accessible, other reasons why transcripts are missing might be due to lack of resources to document. Informal interviews with individuals who monitored the hearings suggest that the commission's capacity to transcribe was uneven. This calls for cautiousness in terms of interpretations of the individual narratives.

Second, the process of identifying the gender of each witness was not always a straightforward task. In most witness statements outside of Colombo, the name of the witness is not provided. In these instances, the gender of the witness has been inferred from the narrative. For instance, in many cases the witness makes reference to for instance "a missing husband," or herself as a "widow."

Despite these shortcomings, the LLRC statements provide a rich material to explore gendered dimensions of public testimonies. In reading the statements, I do so in the role of an outsider. Being a Western-based scholar, my academic engagement with Sri Lanka goes back to 2002, and I have since been involved in several research projects which have brought me to different parts of Sri Lanka (including the war-affected areas) on a regular basis. For this specific project, I conducted four visits $(2012,2014,2015$, and 2016). Approximately half of the time was spent in Colombo, but I also traveled to the North (Jaffna, Mullaitivu, and Kilinochchi) and the East (Trincomalee and Muttur). ${ }^{6}$

In total, I accessed 547 transcribed individual statements. Table 1 summarizes the gender distribution of available public testimonies per district.

This overview suggests that more women than men testified in the public hearings. Of the testimonies where the gender of the witness is clearly identifiable, 50 percent (275) were women, while 22 percent (122) were men. For the remaining 27 percent (150), it was not possible to identify the gender with certainty. The analysis focuses on transcripts of statements by women from the public hearings from districts in the Northern Province and Eastern Province, in total 267.

When analyzing the testimonies, a limitation of transcribed testimonies has been considered: there is "an ease of empathy, a suspension of critical judgement, in listening and watching which is not present in the same way when reading the testimonies ... transcribed testimonies sometimes yar: events do not follow one another clearly, the

\footnotetext{
${ }^{5}$ All available documents were downloaded from the official LLRC website (www.llrc.lk) by a research assistant in September 2014 and are available from the author upon request. Written submissions and transcripts of a few individuals are available at the LLRC Archives (www.llrcarchive.org), a website hosted by the International Centre for Ethnic Studies.

${ }^{6}$ On these visits, I held interviews with human rights groups/experts, women's groups/organizations, as well as women who had testified in the LLRC, and/or the Presidential Commission to Investigate into Complaints Regarding Missing Persons. I am not fluent in either Tamil or Singhalese and relied on research assistants for translation when needed.
} 


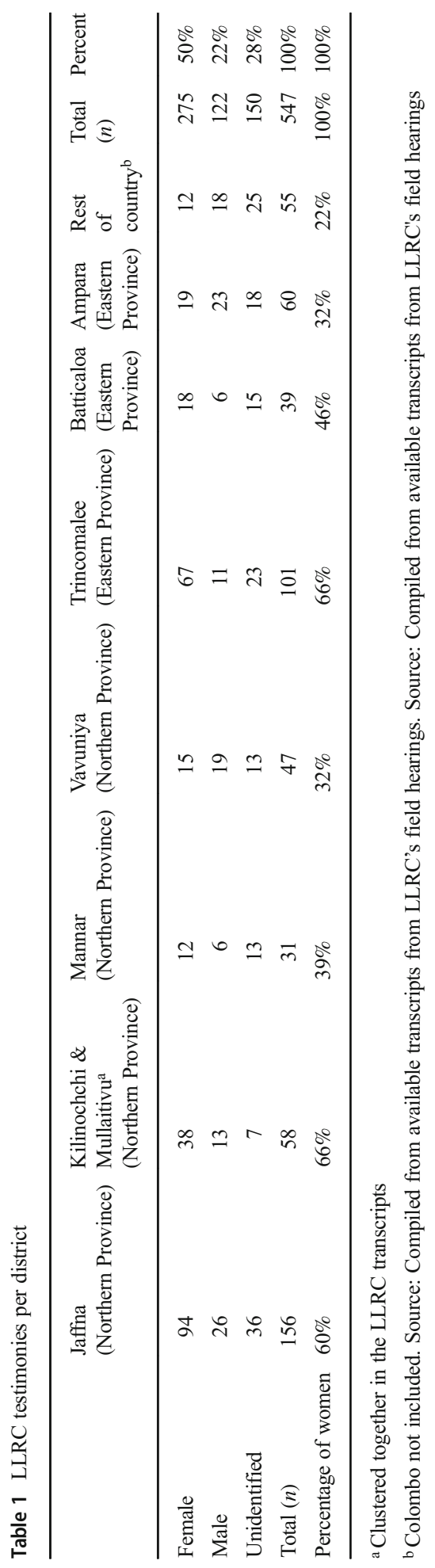


narrative may seem incoherent, and the taken-for-granted nature of information and idiom does not easily survive translation" (Ross 2003, p. 35). For this reason, I begin by discussing the approach of the Commission, before probing the main themes and silences identified in the testimonies in relation to the context and timing of the commission.

\section{Approach of the Commission}

Commissions have different approaches and procedures surrounding the public hearings, which may prevent or facilitate truth-telling and influence the testimonies (Hayner 2011). For instance, the public hearings in the South African TRC became highly ritualized and the style of questioning by the commissioners very different from a courtroom. As an example, each witness was given a "dignified welcome" and it was acknowledged that their testimonies were important. Food and drinks were offered. Moreover, the "questioning commissioner would adopt a gentle, respectful tone" (Bozzoli 1998, p. 176).

The transcripts from LLRC offer a very different picture of the LLRC proceedings. Overall, based on a reading of the testimonies, I find few empathetic gestures from the commissioners. ${ }^{7}$ In their inquiry, the commissioners are asking for complaints/problems, and not encouraging the witnesses to "tell their stories." Oftentimes, witnesses are interrupted when they want to speak of their own experiences and are asked to focus on their "immediate problem." For instance, a woman testifying at the District Secretariat in Kilinochchi (Witness 1, Kilinochchi, 18/11/2010) relates how her sons are missing (and later also that two other sons have been killed), but also refers to her own injury. However, the questioning commissioner interrupts her:

A. I have 7 children -4 boys. Of the 4 boys 2 boys are missing. 1 is married and has 3 children and those children are also with me. I am the supporting member of the family.

Q. What happened to your (2) sons?

A. I am also short of hearing because of shell attack. There are shell pieces still in my ...

Q. No, ask her what happened to her sons?

Similarly, the following line of inquiry in Poonagari/Pooneryn in the Northern Province $(18 / 11 / 2010)$ is emblematic of interrupted storytelling:

3rd Witness: I do not know whether my daughter is alive or not.

Chairman: What happened to your daughter?

3rd Witness: We went through untold sufferings.

Chairman: But what happened to your daughter?

The interruptions raise questions about how the proceedings of public hearings can ensure that women witnesses are comfortable in retelling the story of their choice (Nesiah 2006). Such concerns led the South African TRC to change its methodology

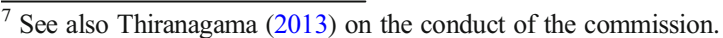


for questioning. The new methodology included gender-sensitive training of the commissioners and a special protocol, to ensure that women were further probed about their own experience of violation and not only the secondary stories (Ross 2003, p. 23). No such action was taken in Sri Lanka. While the commissioners were very experienced and most of them had a background in the legal profession, the LLRC did not have any provisions to look at gender-based violence specifically and there was no gender training for the LLRC (de Mel 2013). There was only one woman in the LLRC, Manohari Ramanathan, and observers have noted that Ramanathan appeared marginalized in the working of LLRC (see Amarathungar 2014). ${ }^{8}$ By contrast, the Task Force set up five years later had a special section on gender and had a more gender-sensitive approach. Its head, Manori Muttetuwegama, was a woman and the Task Force's recommendations included a number of specific provisions concerning women, such as gender-sensitivity training for public servants.

The experience of Sri Lanka (as well that of South Africa's TRC) suggests that with time and learning, transition justice initiatives can adopt its format to facilitate other types of stories to be heard. However, the timing of the LLRC posed limitations on the public testimonies emerging from the hearings. Intimidation of witnesses by both paramilitary groups and the military was reported before and during the hearings (Amnesty International 2011, p. 53; Centre for Human Rights 2011, pp. 18-19), and several women have reported harassment after testifying about disappearances (Fonseka 2017 , p. 5). These examples follow a general pattern of militarization, surveillance, and intimidation found in Sri Lanka's war-torn areas after the war came to an end. For instance, Satkunanathan (2016, p. 417) has documented pervasive military surveillance, including of "any gathering of more than a handful of people," and how such practices have had a negative influence of the rebuilding of community-level trust.

More generally, access to the LLRC sessions seems to have been uneven. The Commission worked with District Secretaries to disseminate information about the LLRC hearings to the residents (Centre For Human Rights 2011, p. 8). However, for each public hearing, there was a large number of individuals turning up and only a few had the opportunity to be heard (Fonseka 2017, p. 5). Many of those approaching the LLRC were individuals who were concerned with missing or detained relatives. To address these concerns despite the limited time the Commission had, those who were not heard in public were asked to give their information in writing to the secretary of the Commission. Moreover, in Pachchillaipallai, the commissioners had been delayed, and when they arrived, most of the people who had come to testify had already left (Amnesty International 2011).

\section{A Plea for the Missing Ones: the Dominating Story and Secondary Witnessing}

Moving from how a generally insecure context and the formal setup of the commission influenced witnesses to come forth to begin with, I continue by uncovering the main themes in the women's statements. What were they and how were they contingent on

\footnotetext{
${ }^{8}$ The commissioners were Chitta Ranjan de Silva Esquire, PC; Dr. Amrith Rohan Perera Esquire, PC; Prof. Mohamed Thahir Mohamed Jiffry Esquire; Prof. Karunaratna Hangawatta Eq; Chandirapal Chanmugam Esq; Hewa Mathara Gamage Siripala Palihakkara Esq; Mrs. Manohari Ramanathan; and Maxwell Parakrama Paranagama Esq.
} 
the timing and context of the commission? A dominant story emerges from my reading of the LLRC testimonies by women from the war-torn north and east of Sri Lanka: one where the witness is asking the Commission for help to find out where her son, daughter, or husband is. Alternatively, the husband, son, or daughter of the witness is in detention and the witness wants him or her released. I contend that two themes follow logically from the context the LLRC was operating in. In 2010, when the Commission conducted the hearings in the war-torn north, a large number of individuals remained in camps. At the end of the war, around 300,000 people were detained. Although the return process was underway when the LLRC began its work, in mid2011 more than 10,000 were still in the main internment camp Menik Farm, and more than 3000 alleged LTTE cadres in what by the government labeled "rehabilitation camps" (International Crisis Group 2011b, pp. 13-17). Moreover, figures from the International Committee of the Red Cross (ICRC) show that in 2016, 16,000 people were still considered missing by their families (International Committee of the Red Cross 2016, p. 3), placing the figure even higher at the time of the LLRC hearings.

The LLRC testimonies cover a large time span, and across different parts of Sri Lanka, the women testify about various actors as responsible for the disappearance, abduction, or internment: the army, the police, the LTTE, or the Karuna group (an LTTE splinter groups). A typical story from Ampara, Eastern Province (25/03/2011) relates:

Witness: My name is Witness 10. I am from Vinayagapuram, Thirukovil. On the 28th of October 2008 at 4.00 p.m. 5 people from Karuna's Group came and took my husband saying that they have an inquiry and after the inquiry he will be allowed to go.

Chairman: How do you know it was the Karuna Group?

Witness: One of the persons in that group was known to us.

Chairman: Who is the person?

Witness: 5 people came. One is Dayabaran whom we know.

Chairman: You have seen him earlier?

Witness: I have not seen him earlier but I know he is married to a girl whom I know. (She says he is in Karuna Group). He is the one who came and took my husband.

In Gurunagar, Northern Province (12/11/2010), a woman testifies about both her husband and son. The story about the husband's fate is very common, where many men disappeared close to the end of the war, as the army was advancing and many surrendered:

Witness 11: Now I don't know where (my husband) is. My son also I don't know his whereabouts. Both of them. We searched for my son at various camps and welfare centres but he is not there.

Chairman: So now you went and surrendered at the Army Camp with your husband?

Witness 11: Yes, in front of us my husband surrendered to the Sri Lankan Army.

Chairman: You also surrendered?

Witness 11: No, I am not a member.

Chairman: Was your husband in the LTTE? 
Witness 11: Yes.

Chairman: So he was in the LTTE.

Witness 11: He was in the LTTE but he is 55 years. He is a marriage registrar for the LTTE. That is only the ... (that was his only function).

Several reflections can be made with regard to the stories about missing or detained close relatives. First, the LLRC testimonies emerging from the war-torn Northern and Eastern provinces by women represent "secondary witnesses," a category to which women witnesses commonly belong within the sphere of public truth-telling after war (Ross 2003, pp. 17-26). With secondary witnesses, women are witnesses primarily in relation to the experiences of the men in their lives (sons and husbands in particular). Few of the statements I analyzed address women's own experiences of being subjected to violence and displacement, despite the prolonged and brutal war.

Second, the women's testimonies often represent economic hardship in the aftermath of the civil war. While economic insecurity is raised as an issue in its own, it is often connected to the disappearance of family members. A woman testifying in Jaffna, Northern Province (12/11/2010), whose husband was taken by unidentified people already in 2006, had been searching since: "Please take steps to trace the whereabouts of my husband and also make arrangements to help us live, for women like me, suffering from poverty and problems like this. Thank you." Another witness in Neerveli, Northern Province (11/11/2010) states:

My problem is that my husband who was the breadwinner is no more and we are living amidst great difficulties because I have 3 children. We were living in a camp and we have now shifted to Jaffna. I was living with my mother and she has also passed away.

However, the burden for the families of the missing transcends economic hardship and intertwines with practical and psychological challenges. De facto widows, or half widows as referred to by Butalia (2002) in the Kashmir context, are those women whose husbands have gone missing but whose bodies are never recovered. This group of women face the challenges of stigma and economic hardship that many widows in Sri Lanka encounter (Jeyasankar and Ganhewa 2018; Ramnarain 2016). As put by Samuel (2001, p. 184), Sri Lankan society "values a married women over a single woman, and a married woman over a widow." However, additionally, de facto widows may lose out on benefits or programs that are offered to women who can legally claim widowhood. A particular challenge relates to the issuing of death certificates and of not having obtained a death certificate (de Mel and Kodikara 2018). As described in an ICRC report: "The majority of the interviewed families reported that they face serious bureaucratic difficulties in the management of family assets registered under the name of the missing person," including the reclaiming of land and accessing benefit schemes (International Committee of the Red Cross 2016, p. iv).

Having a missing family member also makes it difficult to cope with trauma and grief (Boss 2009). In the absence of reliable and concrete information about the missing person, many women believe their missing family members are still alive. The ICRC report mentioned above states that 31 percent of those surveyed believe that their 
missing ones remain alive, and another 33 percent were uncertain of whether their relative was dead or alive (International Committee of the Red Cross 2016, p. 16).

By being dominated by secondary witnesses and with a focus on the economic dimensions of loss, the LLRC testimonies intimate something about womanhood in Sri Lanka, especially in the context of war. When women testify on behalf of others - their husbands, sons, and daughters - and define their suffering primarily in relation to the loss of their family members, they reaffirm existing gender constructions. In Sri Lanka, women's position in their communities and families will depend on a number of factors - including class, religion, ethnicity, and political context. ${ }^{9}$ However, Ruwanpura (2006) identifies important commonalities across Sri Lanka's ethnic communities, where women-headed households remain trapped in patriarchical structures, also the communities in Sri Lanka that are matrilineal by tradition. In this way, women testifying as secondary witnesses may be interpreted to confirm a traditionalist discourse of womanhood where "women are conceptualized on the basis of their relation with men: they are daughters, sisters, wives and mothers, not persons in their own right" (Schrijvers 2011). The testimonies, thus, privilege certain representations over others, and fail to disclose the multiple forms of suffering Sri Lankan women were subjected to during the war.

The focus on the economic dimensions of loss also illuminates how elements of power and authority are introduced into the individual hearings. Sri Lanka is a society where men are conceived of as the "breadwinners and sustainers of their families and women ideally suited to their roles of housewife and mother" (de Alwis 2002, p. 681). It is therefore illustrative that witnesses often start not only by stating their name and where they are from, but also their profession and economic status. When addressing the Commission, they, for instance, often state that they are unemployed, or their (late) husband's profession rather than their own. As exemplified by a woman who testified in Neervely village on the Jaffna peninsula, Northern Province (11/11/2010):

Witness 1: I am from Kalviyankadu. My husband X1 was a driver. On the 15th of December 2007 he was abducted by unidentified gunmen. I have 4 female children. While he was sleeping at home he was taken.

In most of the testimonies by women from the Northern and Eastern provinces, there is a tone of despair accompanied by humbleness. In fact, there is no focus on accountability, and only rarely demands for compensation. A woman addressing the Commission at Vadukkodai East, Jaffna, Northern Province (12/11/2010), whose husband was in the LTTE but who had not been heard from after the war, is elucidating. The woman had been looking for him in several of the detention camps where the army kept suspected LTTE cadres, but feared that he had been shot by the government: "I make a humble request to you to find out whether my husband is alive or not." Another woman testified about the events surrounding the last stages of the war, when they were crossing from LTTE-held areas to army-controlled areas under heavy fire. Her daughter, son-in-law, and one grandchild sustained injuries from the shelling and died. Her second grandchild was also injured, but she expresses hope that he is alive. All she asks from the Commission is help in tracing him (Mullaithivu, Northern Province, 20/09/2010).

\footnotetext{
${ }^{9}$ Tamil womanhood is also influenced by caste, see, e.g., Rajasingham-Senanayake (2004) and Jeeweshwara Räsänen (2015).
} 
In essence, these testimonies are more about demands for truth and repair of family relations, than about accountability or compensation. de Mel's study confirms this view and suggests that the voicing of concerns about disappeared loved ones was important for those bearing witness. The women testifying in the LLRC expressed appreciation for the opportunity; it was seen as a form of recognition of their suffering, an occasion to get information about their missing ones, and they were not interested in punishment (de Mel 2013, p. 11). This perspective by the women may be linked to a pragmatic approach to justice present in many post-war societies, including in Sri Lanka (de Mel 2013, p. 11; see also Gunatilleke 2015, p. 65). However, I contend that that a pragmatic approach in the quest for truth is also symptomatic of the insecurities and uneven power relations following a victor's peace that prevailed in Sri Lanka at the time, where the pursuit of justice and accountability were commonly portrayed as attempts at vengeance (Saravanamuttu 2017).

\section{Silence and Agency}

My reading of the LLRC testimonies by women in Sri Lanka's Northern and Eastern provinces reveals two main silences that concern how the women's war and post-war experience are represented: silences around ongoing insecurities and silences that pertain to sexually motivated atrocities during the war. How can the silences be understood and how do they relate to the context and timing of the LLRC commission?

Silences concerning current insecurities are important, because of the interwoven nature between silences about past and ongoing abuses. As Nicola Henry notes (2009, p. 1100): "silence is counterproductive to recognition and justice," by securing impunity not only for war-related atrocities, but also for ongoing crimes. My reading of the LLRC transcripts from the Northern and Eastern provinces reveals that there are only some statements by women from these areas testifying to ongoing insecurities after the war came to end. Analyzed alongside descriptions of the situation on the ground by human rights organizations and observers, statements about new or residual insecurities are in fact remarkable very few. This discrepancy may be expected given that post-2009 insecurities were not the focus of the LLRC, and because of ongoing government control and militarization dominating this period of post-war Sri Lanka. Several security challenges have been described. In the war-torn north and east, many women were dependent on the military for everyday needs, with heightened risk for genderbased violence (Satkunanathan 2018). For instance, "[s]exual harassment by the military remains a daily reality for Tamil women, particularly young women, who must engage with state forces for basic activities ranging from purchasing vegetables to school registration. In areas with little electricity, many women's only opportunity to charge their cell phones is to visit the nearest military camp" (Gowrinathan and CroninFurman 2015, p. 9). Rehabilitated ex-combatants, including women, were frequently subject to military surveillance and arbitrary arrest, torture, and disappearance (Gowrinathan 2013; International Crisis Group 2011a; International Crisis Group 2017; Krishnan 2012). de $\operatorname{Mel}$ (2017, p. 7) notes such pervasive militarization in post-war Sri Lanka as contributing to the silencing of women.

In this context, women who came to testify challenge the view of the passive victim, and witnessing can be interpreted as an act of bravery. The women's representations tells the story of women who went to the LLRC with a mission-most often to find 
their missing family members - and were willing to take the risks associated. Research from other contexts reports similar sentiments among those choosing to testify (Stover 2007, p. 3). The war experience and ongoing insecurities have victimized women in Sri Lanka, and the LLCR testimonies bring out their suffering. However, given the large number of women in the war-torn north that chose to testify-despite the residual insecurities and high level of militarization - the LLRC may also be interpreted as a platform that helped to contest the common picture of women as passive victims, and that demonstrates the agential power of the women witnesses (Björkdahl and Mannergren Selimovic 2015; Seoighe 2016, p. 373).

While taking note of the agential power of the LLRC witnesses, a main contradiction captured in the reading of women witness statements from the Eastern and Northern provinces concerns the absence of testimonies pertaining to sexually motivated warrelated abuse. Apart from so-called secondary witnesses, women's testimony in public truth-telling usually concerns such crimes, to disclose an important component of many women's war experience (Ross 2003, p. 17-26; see also Franke 2006, p. 813). Yet, in the LLRC statements from localities in Sri Lanka's war-torn areas, experiences of sexual violence constitute a major silence. In only a few of the LLRC witness statements are such atrocities mentioned. The only LLRC testimony that concerns the revelation of personal experience of sexual violence is from Kalmunai, Eastern Province $(27 / 03 / 2011)$ where a witness narrated:

Witness 12: One of my sisters who was 10 years old was rounded up by the Army and the EPDP and she was raped and she is now mentally retarded ... And they harassed me, they beat me, they assaulted me. I sustained a lot of injuries on my legs. They pricked nails to my hands and also they descended to the level of sexual harassment. And when I cried for water they gave me urine. After that I was taken to a room and locked. I am a heart patient. When I complained to them they did not listen to me.

In addition, there are a few testimonies concerning sexual abuses more generally, for instance, as here by a woman in Trincomalee, Eastern Province (3/12/2010):

Witness 7: But, many of our people had been kidnapped; children were abused, sexually abused and some of them were killed. I have come with the confidence that the people who had faced through all these ordeals are here. They have come here with the confidence that the commission provides some positive response to the problems and to the suffering of the people.

Again, this silence on sexually related crimes stands in contrast to the reports by human rights organizations, which have brought attention to sexual violence and exploitation both during the war and after it has ended (HRW 2013; Sooka 2014; Traunmüller et al. 2017). The silences around sexual abuses in the LLRC must be understood against the background of the LLRC being a formalized setting, a lack of probing into these issues by the commissioners, and an absence of gender-sensitive measures, which may have made it possible for women to speak about these issues more safely. But there is more to this silence than the formal setup of the LLRC, including the general stigma associated with the revealing of sexual violence in the context of conflict, but also 
more generally (which is true for Sri Lanka as well as most societies) (Woodworth 2017). As explained by Satkunanathan (2015):

locally it has been challenging to document cases of sexual violence that took place during the war since women are reluctant to speak of it openly due to numerous reasons, including fear of reprisals from perpetrators, particularly if they happen to be state actors, social stigma and belief they will not obtain any redress. Even when they share their stories, most often they do not wish these stories to be made public. The silence they maintain, particularly following the end of the war, was possibly their way of normalizing life and switching to survival mode in the militarized and repressive post-war phase. They may also maintain silence due to fear of losing control of their stories once they are in the open. When a story of sexual violence becomes public numerous actors including the state, the diaspora, human rights activists, and political parties amongst others, capture the story, which is then portrayed and used in different ways to further varied agendas.

This observation by Satkunanathan reveals how women witnesses in Sri Lanka-as around the globe-face a number of risks, including social stigmatization and retraumatization, when previously private stories are narrated (Brounéus 2008; Franke 2006, p. 813; Mibenge 2013; Ross 2003). Even in situations where commission mandates explicitly have included gender-based violence, testimonies of rape in the first person were rare, as uncovered by Kimberly Theidon (2007) in the Peruviuan TRC. Silences may be due to fear, shame, and what has been labeled the "impossibility of bearing witness" (Falcon 2005; Henry 2010). As Butalia (2018, p. 267) asks in relation to the widespread sexual abuse (including rape) of women during the violent partition of India: "Even if the women wanted to remember, what would they remember? With whom would they remember? In order to be meaningful, memories have to be shared but if you are alone, if that memory is shameful, if there is no one to allow it as legitimate, how do you remember? ... how would you struggle even to find a vocabulary that could adequately capture that pain and violation, if articulating the memory will not lead to any healing, any route to justice?"

In this sense, the absence of representations about sexually related crimes in the LLRC may have more to do with the social and individual processes, than the immediate post-war context that can help us explain why ongoing insecurities were not raised to any great extent. However, silences can also constitute a form of agency: it can be a deliberate choice to avoid the risks associated with testifying about hidden and traumatic experiences, and serve to protect close relationships (Mannergren Selimovic 2018; Motsemme 2004; Porter 2016).

\section{Conclusion}

The LLRC failed to deliver justice to those who suffered the most from the war and to address the needs of women in post-war Sri Lanka (Thiranagama 2013). Ten years after the war came to a military halt, Sri Lanka struggles to come to terms with the major human rights abuses of the war, and to provide answers to family members still 
searching for missing family members. By engaging in a close reading of women's LLRC statements in the most conflict-affected areas of Sri Lanka, this paper attempts to foreground the significance of the context and timing of the commission for how women chose to represent their war-related experiences and post-war concerns. As such, it speaks to broader questions pertaining to the gendered nature of transitional justice initiatives, and of public testimony in authoritarian settings.

First, attention to the timing and context helps to uncover the gendered dimensions of transitional justice efforts, such as public inquiries geared towards truth-telling and fact-finding. The narratives (and silences) coming forth tell of how women represent events and experiences during and after the war, and how they-at this moment in time - chose to voice their main concerns. In the context of immediate aftermath of war in an authoritarian setting, the commission was not used for truth-telling, or for accountability, or for reconciliation. Rather, the testimonies were given in order to seek information about missing family members and to give voice to a dire economic situation. Important silences - especially around the women's own conflict and postwar-related experiences, including of sexual violence and of ongoing insecuritieswere also contingent on the timing and conduct of the commission. Silence is a protective measure in a social and political situation where support is unlikely to be forthcoming. In addition, in the absence of gender-sensitive questioning and training of the Commission, and in the face of a type of questioning that demanded facts and clarity, rather than a sharing of experiences, the witness stories typically became limited, directed, and scripted.

Second, the analysis underscores the predicaments of public testimony in authoritarian settings. The experience of the LLRC reaffirms Wilson's (2001) observation about the political nature of "reconciliation" commissions, where political elites may praise reconciliation to evade accountability. In Sri Lanka, the timing of the LLRC meant that testimony was given within an overall narrative focused not on punitive justice or truth-telling, but on a "home-grown approach" formulated within a victor's peace. Reconciliation between Sri Lanka's ethnic groups was a main theme of the official post-war narrative, and the LTTE was constructed as the single perpetrator responsible for all war-related ills (Schubert 2013; see also Gunatilleke 2015, p. 91). As such, the LLRC reveals important dilemmas associated with public testimony in authoritarian regimes and post-war settings where the regime is not ready to take concrete measures to address the structural dimensions of the conflict. On the one hand, the collection of stories or information would at least in theory enable immediate redress and in the long-term function as an "archive for truth." On the other hand, as noted by Alcalá and Uribe (2016, p. 9), public testimony without security raises questions about "whose victims' voices gain authority in the documentation process; and the risks of institutionalizing a discourse around victims that bestows narrative capital to state and societal institutions."

In war-torn societies across the world, women constitute a driving force in the search for the disappeared. A key recommendation of the final report of the LLRC-based on the witness statements - was that "a comprehensive approach to address the issue of missing persons should be found as a matter of urgency as it would otherwise present a serious obstacle to any inclusive and long-term process of reconciliation" (LLRC 2011, p. 339). The 2017 final report of the Consultation Task Force, that held public consultations on the government's transitional justice policies across Sri Lanka, 
reiterated the same point: "disappearances constituted the most recurrent and pressing issue brought before the CTF" (Consultation Task Force on Reconciliation Mechanism 2017, p. 176). The LLRC as well as subsequent transitional justice initiatives, thus, have raised expectations of redress among the survivors of the war. However, as the search for the missing continues, promises by the state remain unfulfilled, upholding the power asymmetry between the state and those who deserve restitution (Guthrey 2016, p. 306).

Acknowledgements This research is funded by the Swedish Research Council, grant 348-2013-170. A first draft of the paper was presented at the ECPG Conference, June 2015. I am grateful to Suna Voss and WaradasThiyagaraja for excellent research assistance, and to Johanna Mannergren Selimovic, Annika Björkdahl, Kate Lonergan, Karen Brounéus and Erika Forsberg for constructive feedback on earlier drafts.

Open Access This article is distributed under the terms of the Creative Commons Attribution 4.0 International License (http://creativecommons.org/licenses/by/4.0/), which permits unrestricted use, distribution, and reproduction in any medium, provided you give appropriate credit to the original author(s) and the source, provide a link to the Creative Commons license, and indicate if changes were made.

\section{References}

Alcalá PR, Uribe MV (2016) Constructing memory amidst war: The Historical Memory Group of Colombia. International Journal of Transitional Justice 10:6-24.

Amarathungar H (2014) Omission of gender: Sri Lanka's Lessons Learnt and Reconciliation Commission. Peace Insight. https://www.insightonconflict.org/blog/2014/06/omission-gender-sri-lanka-reconciliation1lrc/. Accessed 10 January 2018.

Amnesty International (2011) When will they get justice? Failures of Sri Lanka's Lessons Learnt and Reconciliation Commission. Amnesty International, London.

Anonymous (2011) Against the grain: pursuing a transitional justice agenda in postwar Sri Lanka. International Journal of Transitional Justice 5:31-51.

Baines E, Stewart B (2011) "I cannot accept what I have not done": Storytelling, gender and transitional justice. Journal of Human Rights Practice. 3:245-263.

Björkdahl A, Mannergren Selimovic J (2014) Gendered justice gaps in Bosnia-Herzegovina. Human Rights Review 15:201-215.

Björkdahl A, Mannergren Selimovic J (2015) Gendering agency in transitional justice. Security Dialogue 46: $165-182$.

Boss P (2009) Ambiguous loss: Learning to live with unresolved grief. Harvard University Press, Cambridge.

Bozzoli B (1998) Public ritual and private transition: The truth commission in Alexandra township, South Africa 1996. African Studies 57:167-195.

Brounéus K (2008) Truth-telling as talking cure: Insecurity and retraumatization in the Rwandan Gacaca courts. 39:55-76.

Buckley-Zistel S, Stanley R (eds) (2012) Gender in transitional justice. Basingstoke, Palgrave Macmillan.

Butalia U (2000) The other side of silence: voices from the partition of India. Duke University Press, Durham.

Butalia U (Ed) (2002) Speaking peace: women's voices from Kashmir. Zed Books, London.

Butalia U (2018) Looking back on partition. Contemporary South Asia 26:263-269.

Centre for Human Rights (2011) The wait for justice. Centre for Human Rights, Colombo.

Consultation Task Force on Reconciliation Mechanism (2017) Final report of the Consultation Task Force on Reconciliation Mechanism, Vol. 1, Colombo.

de Alwis M (2002) The changing role of women in Sri Lankan society. Social Research 69:675-691.

de Mel N (2007) Militarizing Sri Lanka: Popular culture, memory and narrative in armed conflict. Sage, Thousand Oaks, CA.

de Mel N (2012) Borders, brokers and the state effect: State-gender relations in Katunayake Free Trade Zone. In: Uyangoda J, de Mel N (eds) Reframing democracy. Social Scientists’ Association, Colombo, pp 201-246. 
de Mel N (2013) The promise of the LLRC: Women's testimony and justice in post-war Sri Lanka. ICES, Colombo.

de Mel N (2017) Risky subjects: Militarization in post-war Sri Lanka In: R Manchanda (ed) Women and politics of peace: South Asia narratives on militarization, power, and justice. Sage, London, pp. 1-20.

de Mel N, Kodikara C (2018) The limits of 'doing' justice: Compensation as reparation in post-war Sri Lanka. In: Mehta D, Roy R (eds) Contesting justice in South Asia. Sage, London, pp 39-73.

de Sayrah A; Wickrematunge (2018) An uneven playing field. Groundviews https://groundviews.org/2018/05 /04/an-uneven-playing-field-harassment-of-female-politicians-in-sri-lanka/ Accessed 11 January 2019.

Department of Census and Statistics (2015) Household income and expenditure survey, 2012-13. Colombo.

DeVotta N (2010) From civil war to soft authoritarianism: Sri Lanka in comparative perspective. Global Change, Peace \& Security 22:331-343.

Falcon JM (2005) The Peruvian Truth and Reconciliation Commission's treatment of sexual violence against women. Human Rights Brief 12:1-5.

Fonseka B (2017) State intervention to transitional justice in Sri Lanka. In: R Manchanda (ed) Women and politics of peace: South Asia narratives on militarization, power, and justice. Sage, London, pp. 1-12.

Franke KM (2006) Gendered subjects of transitional justice. Columbia Journal of Gender \& Law 15:814-828.

Gamburd MR (2011) Female labor migration from Sri Lanka to the Middle East. In: Holt JC (ed) The Sri Lanka reader. Duke University Press, London, pp 687-694.

Gowrinathan N (2013) Inside camps, outside battlefields: Security and survival for Tamil women. St Antony's International Review 9:11-32.

Gowrinathan N, Cronin-Furman K (2015) The forever victims? Tamil women in post-war Sri Lanka. Colin Powell School for Civic and Global Leadership, New York.

Grodsky B (2008) Justice without transition: Truth commissions in the context of repressive rule. Human Rights Review 9:281-297.

Gunatilleke G (2015) Confronting the complexity of loss: Perspectives on truth, memory \& justice in Sri Lanka. Law and Trust Society, Colombo.

Guthrey H (2016) Expectations and promises in the quest for truth: Examining victims' perceptions of truth commission participation in Solomon Islands and Timor-Leste. Peace and Conflict: Journal of Peace Psycholgy 22:306-317.

Hamber B, Wilson RA (2002) Symbolic closure through memory, reparation and revenge in post-conflict societies. Journal of Human Rights 1:35-53.

Hayner P (2011) Unspeakable truths: Transitional justice and the challenges of truth commissions. Routledge, Abington.

Henry N (2009) Witness to rape: The limits and potential of international war crimes trials for victims of wartime sexual violence. International Journal of Transitional Justice 3:114-134.

Henry N (2010) The impossibility of bearing witness: Wartime rape and the promise of justice. Violence Against Women 16:1098-1119.

Hinton AL (ed) (2010) Transitional justice: Global mechanisms and local realities after genocide and mass violence. Rutgers University Press, New Brunswick.

Hoole R et al (1990) The broken palmyra, The Sri Lanka Studies Institute, Claremont CA.

Human Rights Watch (HRW) (2013) "We will teach you a lesson": Sexual violence against Tamils by Sri Lankan security forces. Human Rights Watch.

International Committee of the Red Cross (2016) Living with uncertainty: Needs of families of missing persons in Sri Lanka. International Committee of the Red Cross, Colombo.

International Crisis Group (2011a) Sri Lanka: Women's insecurity in the north and east. International Crisis Group, Brussels.

International Crisis Group (2011b) Reconciliation in Sri Lanka: Harder than ever. International Crisis Group, Brussels.

International Crisis Group (2017) Sri Lanka's conflict-affected women: Dealing with the legacy of war. International Crisis Group, Brussels.

Jazeel T, KN Ruwanpura (2009) Dissent: Sri Lanka's new minority? Political Geography 28:385-387.

Jeeweshwara Räsänen B (2015) Caste and nation-building: Constructing Vellalah identity in Jaffna. University of Gothenburg, Gothenburg.

Jeyasankar V, Ganhewa S (2018) Making ends meet: Women's livelihoods in Post-War Sri Lanka. International Centre for Ethnic Studies, Colombo.

Karstedt S (2010) From absence to presence, from silence to voice: Victims in international and transitional justice since the Nuremberg trials. International Review of Victimology 17:9-30.

Kent L (2014) Narratives of suffering and endurance: Coercive sexual relationships, truth commissions and possibilities for gender justice in Timor-Leste. International Journal of Transitional Justice 8:289-313. 
Kent L (2016) After the truth commission: Gender and citizenship in Timor Leste. Human Rights Review 17:51-70.

Kottegoda S (2010) Gender, power and politics. In: Orjuela C (ed) Power and politics: In the shadow of Sri Lanka's armed conflict. Sida, Stockholm, pp 79-100.

Krishnan SI (2012) The transition to civilian life of teenage girls and young women ex-combatants: A case study from Batticaloa. International Centre for Ethnic Studies, Colombo.

Lessons Learnt and Reconciliation Commission (LLRC) (2011) Report of the commission of inquiry on Lessons Learnt and Reconciliation. Colombo.

Mannergren Selimovic J (2018) Gendered silences in post-conflict societies: a typology. Peacebuilding. https://doi.org/10.1080/21647259.2018.1491681

McLeod L (2013) Back to the future: Temporality and gender security narratives in Serbia. Security Dialogue 44:165-181.

Meyers DT (2016) Victims' stories and the advancement of human rights. Oxford University Press, Oxford.

Mibenge C (2013) Sex and international tribunals: The erasure of gender from the war narrative. University of Pennsylvania Press, Philadelphia.

Moon C (2006) Narrating political reconciliation: Truth and reconciliation in South Africa. Social \& Legal Studies 15:269.

Motsemme N (2004) The mute always speak: On women's silences at the truth and reconciliation commission. Current Sociology 52:909-932.

Mueller-Hirth N, Rios Oyola S 2018 Time and Temporality in Transitional and Post-Conflict Societies. Routledge, London.

Nesiah V (2006) Truth commissions and gender. International Centre for Transitional Justice, New York.

Orjuela C (ed) (2010) Power and politics: In the shadow of Sri Lanka's armed conflict. Sida, Stockholm.

Pereira AW (2003) Political justice under authoritarian regimes in Argentina, Brazil and Chile. Human Rights Review. 4:27-47.

Perera J, Gunawardane N, Jayasuria V (2011) Review of research evidence on gender based violence (GBV) in Sri Lanka. Sri Lanka Medical Association, Colombo.

Pinto-Jayawardena K, de Almeida Guneratne J (2010) Is land just for men? Law and Society Trust, Colombo.

Porter E (2016) Gendered narratives: Stories and silences in transitional justice. Human Rights Review 17:35-50.

Rajasingham-Senanayake D (2004) Between reality and representation: Women's agency in war and postconflict Sri Lanka. Cultural Dynamics 16:141-168.

Rameez A (2018) Political participation of women in local governance: A case study of selected local government bodies in Eastern Sri Lanka. Journal of Asian and African Studies 53:1043-1061.

Ramnarain S (2016) Unpacking widow headship and agency in post-conflict Nepal. Feminist Economist 22: $80-105$.

Ross FC (2003) Bearing witness: Women and the Truth and Reconciliation Commission in South Africa. Pluto Press, London.

Rosser E (2007) Depoliticised speech and sexed visibility: Women, gender and sexual violence in the 1999 Guatemalan Comisión para el Esclarecimiento Histórico Report. International Journal of Transitional Justice 1:391-410.

Rowen I, Rowen J (2017) Taiwan's Truth and Reconciliation Committee: The geopolitics of transitional justice in a contested state. International Journal of Transitional Justice 11:92-112.

Ruwanpathirana, T (2016) Memorialisation for transitional justice in Sri Lanka. Centre for Policy Alternatives, Colombo.

Ruwanpura KN (2006) Matrilinear communities, patriarchical realities: A feminist nirvana uncovered. University of Michigan Press, Ann Arbor.

Samuel K (2001) Gender differences in conflict resolution: The case of Sri Lanka. In: Skjelsbæk I, Smith D (eds) Gender, peace and conflict. Sage Publications, London.

Samuel K (2017) Building transversal solidarities: women's search for peace in Sri Lanka. In Manchanda R (ed) Women and politics of peace: South Asia narratives on militarization, power, and justice. Sage, London.

Saravanamuttu P (2017) The Politics of Transitional Justice in Sri Lanka. In: Fonseka B (ed) Transitional justice in Sri Lanka: moving beyond promises. Centre for Policy Alternatives, Colombo, pp 43-60.

Sarvananthan M, Suresh J, Alagarajah A (2017) Feminism, nationalism, and labour in post-civil war Northern Province of Sri Lanka. Development in Practice 27:122-128.

Satkunanathan A (2015) What is represented and what is made invisible: women and transitional justice processes in Sri Lanka. Groundviews http://groundviews.org/2015/06/03/what-is-represented-and-whatis-made-invisible-women-and-transitional-justice-processes-in-sri-lanka/ Accessed 10 January 2018. 
Satkunanathan A (2016) Collaboration, suspicion and traitors: an exploratory study of intracommunity relations in post-war Northern Sri Lanka. Contemporary South Asia 24:416-428.

Satkunanathan A (2018). Sri Lanka: The impact of militarization on women. In: Ní Aoláin F et al (eds) The Oxford handbook of gender and conflict. Oxford University Press, New York.

Schaffer K, Smith S (2004) Human rights and narrated lives: The ethics of recognition. Palgrave Macmillan, New York.

Schrijvers J (2011) Womanhood and the Tamil refugee. In: Holt JC (ed) The Sri Lanka reader: History, culture \& politics. Duke University Press, London, pp 523-541.

Schubert A (2013) Victorious victims: An analysis of Sri Lanka's post-war reconciliation discourse. International Centre for Ethnic Studies, Colombo.

Sen U (2011) Spinster, prostitute or pioneer? Images of refugee women in post-partition Calcutta. European University Institute, Florence.

Seoighe R (2016) Discourses of victimization in Sri Lanka's civil war: Collective memory, agency, legitimacy and agency. Social and Legal Studies 25:355-380.

Sivachandran S (2013) Women headed families in the Northern Provinces. Centre for Women and Development, Jaffna.

Sooka Y (2014) An unfinished war: Torture and sexual violence in Sri Lanka, 2009-2014. International Truth and Justice Project, Sri Lanka.

Stover E (2007) The witnesses: War crimes and the promise of justice in the Hague. University of Pennsylvania Press, Philadelphia.

Thaheer M, Peiris P, Pathiraja K (2013) Reconciliation in Sri Lanka: Voices from former war zones. International Centre for Ethnic Studies, Colombo.

Theidon K (2007) Gender in transition: Common sense, women and war. Journal of Human Rights 6:453478.

Thiranagama S (2013) Claiming the state: Postwar reconciliation in Sri Lanka. Humanity 4:93-116.

Traunmüller R et al. (2017) The silent victims of wartime sexual violence: Evidence from a list experiment in Sri Lanka. Available at SSRN: https://ssrn.com/abstract=2937943. Accessed 8 March 2019.

UNHCR (2015) UNHRC Resolution 30/1, 2015.

Wickramasinghe M, Kodikara C (2012) Representation in politics: Women and gender in the Sri Lankan republic. In: Welikala A (ed) Republic at 40. Centre for Policy Alternatives, Colombo, pp 19-24.

Wilson RA (2001) The politics of truth and reconciliation in South Africa: Legitimizing the post-apartheid state. Cambridge University Press, Cambridge.

Woodworth A (2017) Judicial accountability for conflict related sexual violence in Sri Lanka. In: Fonseka B (ed) Transitional justice in Sri Lanka. Centre for Policy Alternatives, Colombo, pp 245-271.

Publisher's Note Springer Nature remains neutral with regard to jurisdictional claims in published maps and institutional affiliations. 